\title{
PENERAPAN PEMBELAJARAN KOOPERATIF TIPE JIGSAW DALAM MENINGKATKAN MOTIVASI DAN HASIL BELAJAR IPA PADA SISWA KELAS VII SEMESTER II SMP NEGERI 2 PULOKULON
}

\author{
Agus Darmadi
}

\begin{abstract}
Abstrak
Permasalahan pokok yang akan dipecahkan lewat Penelitian Tindakan Kelas ini adalah: apakah penerapan model pembelajaran kooperatif tipe jigsaw dapat meningkatkan hasil belajar IPA. Tujuannya untuk meningkatkan motivasi dan hasil belajar siswa dalam mata pelajaran IPA..

Penelitian ini merupakan tindakan guru untuk memperbaiki hasil belajar siswa kelas VII SMP Negeri 2 Pulokulon Semester 2 Tahun Pelajaran 2013/2004, dan pelakunya adalah guru IPA. Penelitian dilakukan dalam 2 siklus dan meliputi 4 tahapan, yaitu perencanaan, tindakan,pengamatan dan refleksi.

Hasil penelitian menunjukkan bahwa dari keseluruhan siklus yang telah dilakukan motivasi dan perolehan nilai siswa kelas VII SMP Negeri 2 Pulokulon Semester 2 Tahun Pelajaran 2013/2004 mengalami peningkatan dari satu siklus ke siklus berikutnya. Jadi secara keseluruhan siklus yang telah dilakukan, penerapan model pembelajaran kooperatif tipe jigsaw dapat meningkatkan motivasi dan hasil belajar siswa dalam mata pelajaran IPA.
\end{abstract}

Kata kunci: Hasil Belajar, Motivasi, Pembelajaran kooperatif jigsaw

\section{PENDAHULUAN}

Sebagai kegiatan yang terprogram, kegiatan pembelajaran perlu dipersiapkan dengan baik. Persiapan itu penting karena akan menentukan keberhasilan kegiatan pembelajaran. Salah satu kegiatan guru dalam rangka persiapan kegiatan pembelajaran adalah menentukan metode atau pendekatan pembelajaran yang tepat untuk siswanya.

Baharuddin (2008: 19) menjelaskan," secara umum faktor-faktor yang mempengaruhi prestasi belajar dibedakan atas dua kategori, yaitu faktor internal dan faktor eksternal. "Faktorfaktor internal meliputi fisiologis dan psikologis. Faktor-faktor fisiologis berhubungan dengan kondisi fisik individu.,

Metode belajar mengajar banyak macamnya antara lain metode ceramah, tanya jawab, diskusi, demonstrasi, eksperimen, quantum learning dan metode pembelajaran dengan pendekatan Cooperative Learning. Dalam suatu kegiatan pembelajaran guru tidak harus menggunakan metode tertentu untuk mengajarkan materi pelajaran, tetapi penggunaan metode lebih ditekankan pada kebutuhan agar sesuai dengan materi pelajaran dan karakteristik pelajaran itu sendiri.

Penerapan metode pembelajaran dengan pendekatan Cooperative Learning dapat meningkatkan self-esteem, kemampuan interpersonal dan menerima kesenjangan akademik di antara siswa. Di samping itu, pendekatan Cooperative Learning dapat mendorong siswa memiliki 
motivasi, keberanian, dan memiliki toleransi terhadap berbagai budaya di dalam kelas yang heterogen.

Berdasarkan latar belakang masalah yang diuraikan di atas, maka identifikasi masalah dalam penelitian ini sebagai berikut: 1) Kurang rutin dilakukannya pembelajaran menggunakan model pembelajaran bervariasi seperti halnya model pembelajaran kooperatif.2) Belum tercapainya hasil belajar siswa sesuai dengan tujuan pembelajaran. 3) Proses pembelajaran hanya bersifat cer amah, sehingga belum dapat menumbuhkan kreatifitas guru dan siswa. 4) Proses pembelajaran cenderung bersifat teacher centered atau berpusat pada guru dan guru mendominasi seluruh kegiatan pembelajaran.

Berdasarkan identifikasi msalah di atas maka rumusan masalah dalam penelitian ini yaitu: 1) Apakah dengan penerapan model pembelajaran kooperatif tipe jigsaw dapat meningkatkan motivasi dan hasil belajar mata pelajaran IPA?

Tujuan Penelitian dalam penelitian ini untuk meningkatkan motivasi dan hasil belajar melalui penerapan model pembelajaran kooperatif tipe jigsaw.

Dari tujuan yang telah dirumuskan di atas, manfaat hasil penelitian ini diharapkan dapat memberikan sumbangan pada dunia pendidikan dan bermanfaat: 1) Manfaat teoritis: Mendapatkan teori baru tentang upaya meningkatkan hasil belajar mata pelajaran IPA melalui model pembelajaran kooperatif tipe jigsaw bagi siswa Sekolah Menegah Pertama Negeri 2 Pulokulon. Dapat digunakan sebagai bahan pertimbangan dan bahan acuan bagi penelitian berikutnya. 2) Manfaat Praktis: Manfaat bagi Kepala Sekolah untuk menekankan kepada guru dapat menggunakan model pembelajaran Cooperative Learning Jigsaw. Manfaat bagi guru sebagai sumbangan pemikiran tentang pengaruh penggunaan model pembelajaran. Manfaat bagi Siswa SMP dapat meningkatkan hasil belajar mata pelajaran IPA.

\section{METODE PENELITIAN}

Penelitian dilaksanakan pada semester 2 Tahun Pelajaran 2013/2004

Pengambilan data dilakukan pada waktu tersebut karena materi yang banyak berkenaan dengan standar kompetensi "memahami berbagai sifat dalam perubahan físika dan kimia".

Tempat penelitian dilaksanakan di SMP Negeri 2 Pulokulon dalam pembelajaran IPA siswa kelas 7 semester 2 Tahun Pelajaran 2013/2004. Alasan penelitian dilaksanakan di sekolah tersebut karena peneliti merupakan guru IPA di sekolah tersebut. Di samping itu, hasil belajar IPA di sekolah tersebut rata-rata rendah

Subjek Penelitian dalam penelitian tindakan kelas ini peneliti adalah guru, maka subjeknya siswa kelas 7A SMP Negeri 2 Pulokulon semester 2 tahun pelajaran 2013/2004 terdiri dari 37 siswa. 
Sumber data dalam penelitian tindakan kelas ini berasal dari subjek penelitian atau dari siswa yang merupakan sumber data primer yaitu nilai ulangan harian siswa baik nilai ulangan harian sebelum tindakan maupun setelah dilakukan tindakan kelas oleh guru.

Teknis tes ini digunakan untuk memperoleh data tentang prestasi belajar IPA siswa kelas 7 SMP Negeri 2 Pulokulon.Instrumen yang dipakai adalah soal-soal disusun oleh peneliti. Penyusunan tes dilakukan dengan melalui kisi-kisi pada mata pelajaran IPA SMP. Soal tes yang dijadikan sebagai instrumen dalam penelitian ini berjumlah 45 butir soal mata pelajaran fisika dalam bentuk tes pilihan ganda dengan 4 alternatif jawaban. Soal yang disusun mewakili kompetensi dasar yang akan dicapai. Soal tersebut disusun dengan kisi-kisi dan perangkat tes terlampir dan disajikan pada lampiran.

Uji validitas tes yang digunakan adalah validitas isi dan empiris yaitu diperoleh dengan membandingkan/berdasarkan kesesuaian antara isi kurikulum dengan soal-soal tes yang disusun. Soal try out sengaja dibuat lebih banyak dengan maksud setelah dilakukan try out dan dianalisis ada soal yang kurang baik dan harus dibuang, maka sudah ada soal lain yang jelas diketahui baik atau tidaknya soal, sehingga tidak perlu lagi membuat soal yang baru.

Instrumen yang dipakai untuk mengumpulkan data dalam penelitian harus benar dan dapat dipercaya sehingga hasil penelitian dapat dipercaya kebenarannya. Oleh karena itu, sebelum instrumen dan penelitian dipakai untuk mengumpulkan data penelitian, maka instrumen penelitian perlu diuji validitas dan reliabilitas.

Untuk memperoleh data yang valid instrumen penelitian terlebih dahulu akan diuji cobakan kepada 40 siswa dan hasil uji coba tersebut diuji validitasnya. Uji validitas digunakan untuk mengetahui apakah instrumen tersebut valid atau tidak. Arikunto (2006:168) mengatakan bahwa "validitas adalah ukuran yang menunjukkan tingkat-tingkat kevalidan atau kesahihan sesuatu instrumen.” Instrumen penelitian yang digunakan adalah soal-soal tes prestasi belajar fisika untuk memperoleh data prestasi belajar fisika dan angket motivasi berprestasi di kelas 7 SMP. Pengujian validitas instrumen dilakukan dengan mempergunakan rumus korelasi product Moment sebagi berikut :

$$
\mathrm{r}_{x y}=\frac{\mathrm{n} \sum \mathrm{xy}-\left(\sum \mathrm{x}\right)\left(\sum \mathrm{y}\right)}{\sqrt{\left.\left[\mathrm{n} \sum \mathrm{x}^{2}-\left(\sum \mathrm{x}\right)^{2}\right] \mathrm{n} \sum \mathrm{y}^{2}-\left(\sum \mathrm{y}\right)^{2}\right]}}
$$

Keterangan :

$\begin{array}{ll}\mathrm{r}_{x y} & =\text { Kooefisien korelasi butir dengan total } \\ \sum \mathrm{x} & =\text { Jumlah skor butir } \\ \sum \mathrm{y} & =\text { Jumlah skor total } \\ \sum \mathrm{x}^{2} & =\text { Jumlah kuadrat skor butir }\end{array}$




$$
\begin{array}{ll}
\sum \mathrm{y}^{2} & =\text { Jumlah kuadrat skor total } \\
\mathrm{n} & =\text { Jumlah responden }
\end{array}
$$

Keputusan Uji:

Kriteria keputusan kevalidan dinyatakan apabila nilai $\mathrm{r}$ yang diperoleh dari hasil perhitungan $\left(\mathrm{r}_{x y}\right)$ lebih besar daripada nilai $\mathrm{r}_{\text {tabel }}\left(\mathrm{r}_{t}\right)$ dengan taraf signifikasi 5\%, maka butir-butir soal adalah valid atau sahih.

Cara pengujian dilakukan dengan bantuan program komputer SPSS 11.0 for Windows.

Setiaji, (2006: 89), besarnya r tiap butir pertanyaan dapat dilihat dari SPSS pada kolom Corrected Items Total Correlation. Kriteria uji validitas secara singkat adalah 0,3. Jika korelasi sudah lebih dari 0,3 pertanyaan yang dibuat dikategorikan valid.

Uji reliabilitas digunakan untuk mengetahui apakah instrumen yang digunakan reliabel atau tidak. Reliabel adalah ketetapan atau keajegan suatu alat ukur. Alat ukur dapat dikatakan reliable apabila dapat dipercaya, stabil atau konsisten. Arikunto (2006: 178) mengatakan bahwa" Reliabilitas menunjuk pada suatu pengertian bahwa sesuatu instrument cukup dapat dipercaya untuk dapat digunakan sebagai alat pengumpul data.

Untuk mengetahui reliabilitas prestasi belajar fisika dan angket motivasi berprestasi digunakan teknik ganjil genap dengan korelasi produk moment, kemudian dilanjutkan dengan menggunakan rumus Spearman Brown untuk mengetahui harga kedua velan (ganjil-genap), sebagai berikut:

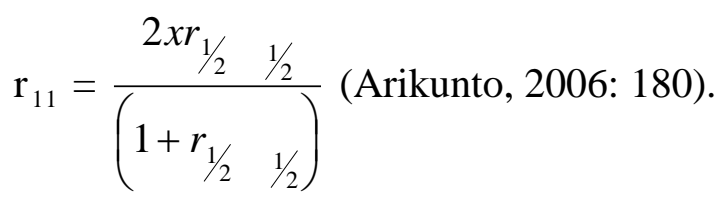

Penghitungan dilakukan dengan mempergunakan program komputer SPSS 11.0 for windows. Insrumen dikatakan reliabel atau handal jika jawaban responden terhadap pernyataan adalah konsisten atau stabil dari waktu ke waktu. Dalam hal ini instrumen dikatakan reliabel apabila nilai $r$ hitung lebih besar dari 0.6 atau lebih (Arikunto, 2006).

Dengan uji reliabilitas instrumen maka akan diketahui taraf keajegan suatu instrumen dalam mengukur apa yang hendak diukurnya. Kriteria yang digunakan untuk menentukan instrumen yang reliabel apabila $\mathrm{r}_{\text {hitung }}>\mathrm{r}_{\text {tabel }}$.

Hasil analisis reliabilitas menggunakan SPSS diperoleh Cronbach Alpha soal tes uji coba 0,9063 dan angket motivasi berprestasi 0,8358 . Karena nilainya lebih besar dari 0,6 ; maka soal tes uji coba maupun angket motivasi berprestasi yang disusun cukup reliabel. 
Penyajian data dalam penelitian ini dalam bentuk tabel, grafik, bagan. Tabel merupakan sajian data mentah yang diambil langsung dari lapangan atau hasil susunan penelitian agar mudah dibaca.

Arikunto, (2007: 487)Yang dikemukakan dalam bagian penyajian data ini adalah paparan atau diskripsi tahap awal tentang data yang berhasil dikumpulkan oleh peneliti.

Jika yang terkumpul sudah berupa tabel, gambar, denah sudah matang dalam arti mudah dipahami maka peneliti tinggal disajikan begitu saja. Akan tetapi jika data yang terkumpul masih berantakan misalnya masih dalam bentuk: uraian, daftar, yang panjang harus dipadukan agar lebih sederhana hingga jelas dan ringkas.

Kegiatan perencanaan (Planing) ini terdiri dari tiga langkah meliputi: dokumentasi kondisi awal, identifikasi masalah dan perumusan masalah. Dokumentasi kondisi awal bertujuan memotret kondisi awal suasana kelas dan kondisi siswa sehingga diperoleh gambaran nyata tentang masalah yang dihadapi. Untuk keperluan ini digunakan daftar nilai dan catatan observasi guru tentang proses pembelajaran yang sudah terlaksana. Identifikasi penyebab terjadinya masalah memerlukan data melalui angket, wawancara dan hasil observasi terhadap siswa kelas 7 SMP Negeri 2 Pulokulon, Kabupaten Grobogan. Masalah yang perlu segera dicari solusinya adalah sebagian besar siswa kelas 7 SMP Negeri 2 Pulokulon, Kabupaten Grobogan, pada tahun pelajaran 2013/2004 memiliki prestasi belajar yang rendah.

Tindakan (Action) Guru memotivasi siswa dan merangsang siswa untuk selalu aktif dalam mengikuti proses pembelajaran IPA, menyusun pencana pelaksanaan pembelajaran (RPP) memuat tindakan-tindakan guru yang merangsang atau menimbulkan keaktifan siswa dalam proses pembelajaran, guru melaksanakan kegiatan inti pembelajaran

Pemantauan (Observing) dilakukan melalui hasil ulangan harian, analisis ulangan harian, wawancara dan observasi kelas.

Perenungan (Reflecting) dari analisis data hasil observasi dilakukan untuk mengetahui sfektifitas dan keberhasilan tindakan perbaikan yang telah dilakukan. Apakah tindakan yang dilaksanakan berhasil mengatasi masalah yang ada atau belum. Hasil refleksi ini selanjutnya digunakan untuk menetapkan langkah-langkah lebih lanjut dalam upaya untuk mencapai tujuan pelaksanaan tindakan. Untuk melihat ketercapaian tindakan yang telah dilakukan dapat dilihat dari hasil ulangan harian, angket, wawancara, observasi kelas dan journal siswa. Apabila tindakan (action) pada siklus I belum menunjukkan hasil yang diharapkan maka disusun rencana dan langkah-langkah tindakan untuk siklus II.

\section{HASIL PENELITIAN}

Setting dalam penelitian tindakan kelas ini adalah siswa kelas 7 A SMP Negeri 2 Pulokulon sebanyak 40 siswa terdiri dari 21 siswa perempuan dan 19 siswa laki-laki. Berdasarkan hasil para 
penelitian, dari 40 siswa tersebut umumnya mengalami kesulitan belajar IPA khususnya stándar kompetensi (SK) “ memahami berbagai sifat dalam perubahan físika dan kimia”. Karakteristik lain yang menonjol dari kelas tersebut adalah sebagian siswa dari kelas tersebut pasif dalam mengikuti pembelajaran, sehingga interaksi belajar mengajar tidak berlangsung dengan baik.

Sebelum dilaksanakan tindakan kelas berupa penerapan model pembelajaran kooperatif tipe jigsaw, terlebih dahulu mencatat data hasil ulangan harian. Kegiatan ini penting dilakukan sebagai dasar pertimbangan perlu tidaknya untuk melanjutkan tindakan kelas yang telah direncanakan.

Data ulangan harian sebelum dilakukan pembelajaran kooperatif tipe jigsaw rata-rata 56, dengan modus 58 median 58 dan standar deviasi 0,62.

\section{Diskripsi Siklus I}

Data hasil belajar IPA siklus I rata-rata 66, dengan modus 68 median 68 dan standar deviasi 0,6. Distribusi frekuensi hasil belajar IPA siklus I selengkapnya dapat disajikan dalam bentuk kelas interval pada tabel berikut:

Tabel 4.3 Distribusi Frekuensi Hasil Belajar IPA Pada Siklus I

\begin{tabular}{ccccc}
\hline Interval & Frekuensi & $\begin{array}{l}\text { Frekuensi } \\
\text { Relatif }\end{array}$ & $\begin{array}{l}\text { Frekuensi } \\
\text { Komulatif }\end{array}$ & $\begin{array}{l}\text { Frekuensi } \\
\text { Komulatif Relatif }\end{array}$ \\
\hline $55-59$ & 3 & $7,5 \%$ & 3 & $7,5 \%$ \\
$60-64$ & 10 & $25 \%$ & 13 & $32,5 \%$ \\
$65-69$ & 15 & $37,5 \%$ & 28 & $70 \%$ \\
$70-74$ & 6 & $15 \%$ & 34 & $85 \%$ \\
$75-80$ & 6 & $15 \%$ & 40 & $100 \%$ \\
\hline
\end{tabular}

Berdasarkan tabel 4.3 diketahui bahwa mayoritas siswa adalah yang memiliki nilai hasil belajar IPA antara 65 - 69 yaitu sebanyak 15 siswa (37,5\%) sedang yang paling sedikit adalah siswa yang memiliki nilai hasil belajar antara 55 - 59 yaitu 3 siswa $(7,5 \%)$

Berdasarkan hasil belajar pada siklus I diketahui bahwa tindakan yang dilakukan peneliti berupa penerapan metode kooperatif tipe jigsaw dapat meningkatkan hasil belajar IPA dibandingkan dengan nilai ulangan harian pada kondisi awal. Ini dapat dilihat yang nilainya dibawah KKM berkurang dari 37 siswa menjadi 13 siswa. Dari data tabel 4.2 menunjukkan siswa yang tuntas baru mencapai 67,5\% artinya belum mencapai $75 \%$ sesuai dengan indikator keberhasilan guru dalam pembelajaran, maka peneliti berpendapat perlu dilakukan siklus II dengan kegiatan yang sama namun kegiatan proses pembelajarannya menggunakan laboratorium IPA.

\section{Diskripsi Siklus II}

Selama proses kegiatan pembelajaran berangsung, guru mengelola kelas secara kondusif, dengan dasar belajar secara menyenangkan, diwarnai dengan reaword secara individu maupun 
kelompok jika dipandang layak dan memberikan punisment jika dipandang perlu. Pada kegiatan ini guru menjelaskan tentang materi berbagai sifat dalam perubahan físika dan nimia sedangkan siswa aktif menyimak, selanjutnya siswa mengikuti pembelajaran kooperatif jigsaw klasikal. Pertama guru membentuk kelompok ( delapan kelompok)masing-masing kelompok terdiri dari 5 orang siswa. Dalam pembelajaran kooperatif model Jigsaw ada dua macam kelompok yaitu, kelompok dasar dan kelompok ahli.Tahapan dalam pembelajaran kooperatif tipe jigsaw yaitu tahap kooperatif, tahap ahli dan tahap lima serangkai.

Data motivasi berprestasi rata-rata 50,641 dengan modus 52 median 50 dan standar deviasi 2,969. Distribusi frekuensi motivasi siswa terhadap mata pelajaran IPA pada siklus II selengkapnya dapat disajikan dalam bentuk kelas interval pada tabel berikut :

Tabel 4.4 Distribusi Frekuensi Motivasi Siswa Terhadap Mata Pelajaran IPA pada Siklus II

\begin{tabular}{ccccc}
\hline Interval & Frekuensi & $\begin{array}{l}\text { Frekuensi } \\
\text { Relatif }\end{array}$ & $\begin{array}{l}\text { Frekuensi } \\
\text { Komulatif }\end{array}$ & $\begin{array}{l}\text { Frekuensi } \\
\text { Komulatif Relatif }\end{array}$ \\
\hline $46-48$ & 2 & $5 \%$ & 2 & $5 \%$ \\
$49-51$ & 8 & $20 \%$ & 10 & $25 \%$ \\
$52-54$ & 15 & $32,5 \%$ & 25 & $57,5 \%$ \\
$55-57$ & 10 & $25 \%$ & 35 & $77,5 \%$ \\
$58-60$ & 5 & $12,5 \%$ & 40 & $100 \%$ \\
\hline
\end{tabular}

Berdasarkan tabel 4.4 diketahui bahwa mayoritas siswa adalah yang memiliki mootivasi berprestasi antara 52 - 54 yaitu sebanyak 15 siswa (40,54\%) sedang yang paling sedikit adalah siswa yang memiliki motivasi belajar antara 46 - 48 yaitu 2 siswa ( $5 \%$ )

Adapun hasil capaian nilai siswa pada siklus II sebagai tolok ukur hasil belajar siswa terhadap penguasaan standar kompetensi berbagai sifat dalam perubahan físika dan kimia dapat dilihat pada tabel di bawah ini:

Tabel 4.5 Distribusi Frekuensi Hasil Belajar IPA Pada Siklus II

\begin{tabular}{ccccc}
\hline Interval & Frekuensi & $\begin{array}{l}\text { Frekuensi } \\
\text { Relatif }\end{array}$ & $\begin{array}{l}\text { Frekuensi } \\
\text { Komulatif }\end{array}$ & $\begin{array}{l}\text { Frekuensi } \\
\text { Komulatif Relatif }\end{array}$ \\
\hline $55-59$ & & & & \\
$60-64$ & 4 & $10 \%$ & 4 & $10 \%$ \\
$65-69$ & 12 & $30 \%$ & 16 & $40 \%$ \\
$70-74$ & 18 & $45 \%$ & 34 & $85 \%$ \\
$75-80$ & 6 & $15 \%$ & 40 & $100 \%$ \\
\hline
\end{tabular}

Berdasarkan tabel 4.5 diketahui bahwa mayoritas siswa adalah yang memiliki nilai hasil belajar IPA antara 70 - 74 yaitu sebanyak 18 siswa (45 \%) sedang yang paling sedikit adalah siswa yang memiliki nilai hasil belajar antara $60-64$ yaitu 4 siswa ( $10 \%$ ) 


\section{Pembahasan Antar Siklus}

Pada keadaan awal ini dapat kita lihat nilai rata-rata hasil belajar siswa 56 dengan prosentase dapat dilihat pada (tabel 4.1)diketahui bahwa mayoritas siswa adalah yang memiliki nilai ulangan harian antara 55 - 59 yaitu sebanyak 16 siswa (40 \%) sedang yang paling sedikit adalah siswa yang memiliki prestasi belajar antara $65-69$ yaitu 3 siswa ( 7,5\%)

Tabel 4.6 Perbandingan Hasil Belajar IPA Pada Siklus I dan II

\begin{tabular}{ccccc}
\hline Interval & $\begin{array}{l}\text { Siklus I } \\
\text { Frekuensi }\end{array}$ & $\begin{array}{l}\text { Frekuensi } \\
\text { Relatif }\end{array}$ & $\begin{array}{l}\text { Siklus II } \\
\text { Frekuensi }\end{array}$ & Frekuensi Relatif \\
\hline $55-59$ & 3 & $7,5 \%$ & & \\
$60-64$ & 10 & $25 \%$ & 4 & $10 \%$ \\
$65-69$ & 15 & $37,5 \%$ & 12 & $30 \%$ \\
$70-74$ & 6 & $15 \%$ & 18 & $45 \%$ \\
$75-80$ & 6 & $15 \%$ & 6 & $15 \%$ \\
\hline
\end{tabular}

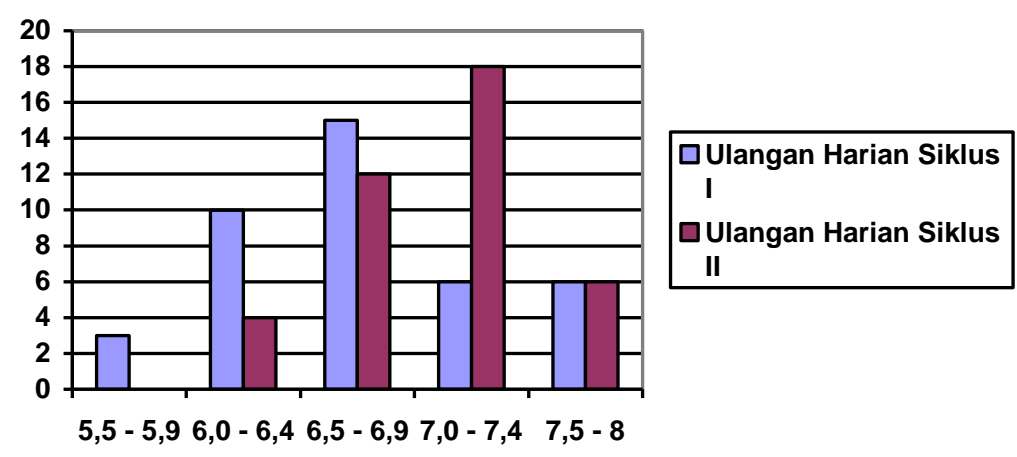

Gambar 4.6 Diagram Batang Perbandingan Hasil Belajar Siklus I dan II

Pada siklus I(tabel 4.6) diketahui bahwa mayoritas siswa yang memiliki nilai hasil belajar IPA antara 65 - 69 yaitu sebanyak 15 siswa (37,5\%) sedang yang paling sedikit adalah siswa yang memiliki nilai hasil belajar antara 55 - 59 yaitu 3 siswa ( 7,5\%), sedangkan pada siklus II mayoritas siswa terletak pada interval 70 - 74 yaitu sebanyak 18 siswa (45 \%) sedang yang paling sedikit adalah siswa yang memiliki nilai hasil belajar antara $60-64$ yaitu 4 siswa ( $10 \%$ ).

Pada siklus II rata-rata hasil belajar 73, siswa yang nilainya di bawah KKM hanya 4 siswa, artinya $80 \%$ siswa secara klasikal telah tuntas. Dengan demikian tindakan penelitian berhenti pada siklus II. Secara keseluruhan pada siklus II ini hasil belajar awal maupun hasil belajar siswa telah menunjukkan peningkatan yang berarti dibandingkan hasil belajar awal maupun hasil belajar siswa pada siklus sebelumnya. Hal ini menunjukkan bahwa penerapan model pembelajaran kooperatif tipe jigsaw dalam pembelajaran berpengaruh terhadap hasil belajar yang dicapai siswa.

Dari hasil penelitian di atas menunjukkan bahwa perolehan nilai siswa selalu mengalami peningkatan dari siklus ke siklus berikutnya. Hal ini mengindikasikan adanya peningkatan hasil belajar siswa terhadap kompetensi dasar berbagai sifat dalam perubahan físika dan kimia. Jadi 
secara keseluruhan siklus yang telah dilakukan, dapat disimpulkan bahwa penerapan model pembelajaran kooperatif tipe jigsaw ternyata dapat meningkatkan hasil belajar siswa terhadap standar kompetensi berbagai sifat dalam perubahan fisika dan kimia. Hal ini nampak jelas pada tabel 4.6, bahwa dalam setiap siklus selalu membawa dampak positif ke arah peningkatan.

Berdasarkan hasil tersebut, maka tindakan yang dirumuskan yaitu: "Melalui penerapan model pembelajaran kooperatif type jigsaw dapat meningkatkan hasil belajar IPA" dapat dibuktikan kebenarannya. Disamping itu pada tabel 4.5 menunjukkan pembelajaran kooperatif tipe jigsaw dapat meningkatkan motivasi siswa terhadap mata pelajaran IPA, dimana terdapat peningkatan yang signifikan.

\section{KESIMPULAN}

Dari hasil penelitian di atas menunjukkan bahwa perolehan nilai siswa selalu mengalami peningkatan dari siklus ke siklus berikutnya. Hal ini mengindikasikan adanya peningkatan hasil belajar siswa terhadap kompetensi dasar berbagai sifat dalam perubahan físika dan kimia. Jadi secara keseluruhan siklus yang telah dilakukan, dapat disimpulkan bahwa penerapan model pembelajaran kooperatif tipe jigsaw ternyata dapat meningkatkan hasil belajar siswa terhadap standar kompetensi berbagai sifat dalam perubahan fisika dan kimia.

\section{DAFTAR PUSTAKA}

Arikunto, Suharsimi 2006. Prosedur Penelitian Suatu Praktek. Jakarta. Rineka Cipta Arikunto, Suharsimi. 2007. Evaluasi Program Pendidikan. Jakarta. PT.Bumi Aksara Baharuddin. 2008. Teori Belajar dan Pembelajaran. Jogjakarta. Ar-Ruzz Media.

B. Hamzah, Uno. 2008. Teori Motivasi dan Pengukurannya. Jakarta: Bumi Aksara

Danim, Sudarwan. 2006. Agenda Pembaharuan Sistem Pendidikan. Yogyakarta: Pustaka Pelajar. Depdiknas. 2006. Undang-Undang Guru dan Dosen. Jakarta: CV. Duta Nusindo.

Gabbin, Alexander, Wood. 2008.“An Experimental Study of Accounting Majors' Academic Achievement Using Cooperative Learning Groups"Issues in Accounting Education. Sarasota: Aug 2008. Vol. 23, Iss. 3; pg. 391, 14 pgs

Gillies, Robyn M.2006. Ten Australian Elementary Teachers Discourse and Reported Pedagogical Practices during Cooperative Learning. The Elementary School Journal. Universitas of Queensland.Academi

Slavin, Robert E. 2008. Cooperative Learning. Bandung: Nusa Media.

Syah, Muhibbin. 2007. Psikologi Belajar. Jakarta: PT Raja Grafindo Persada.

Syaodih, Sukmadinata. 2003. Landasan Psikologi Proses Pendidikan. Bandung: Pt Remaja Rusdakarya.

Wartono.2004.Model-model Pengajaran Dalam Pembelajaran Sain.Jakarta: Bagian Proyek Pengembangan sistem dan Pengendalian Program. 